\title{
From bottom of the pyramid to top priority: Explaining Asia in the EU's Free Trade Agreement (FTA) Strategy
}

\author{
MARI A GARCIA \\ NCRE, University of Canterbury \\ maria.garcia@canterbury.ac.nz
}

\begin{abstract}
Over the past two decades the economic relations between the European Union and Asia have increased exponentially, yet policy responses have lagged behind. Tracing EU official documents since the mid-1990s, this paper shows how the EU continues to perceive its position in Asia as weak, and how it has been shaped by USA actions in the region, and competitiveness concerns. The paper focuses on current trends in free trade agreement negotiations and argues that the EU's policy has been guided by fear of competition with the USA, and to a lesser extent with Japan and China. A short case study section compares the EU and USA FTAs with South Korea (the only ones finalized thus far) and shows how their similar content reveals a game of competition and of preventing future discrimination. A final section draws some implications from this case study for ongoing negotiations in the region.
\end{abstract}

Keywords: Competition, EU-Asia, EU external relations, Free trade agreements, Negotiations, Trade policy

\section{Introduction}

Over the past decades economic relations between the EU and Asia have increased exponentially, yet policy has lagged behind. This article addresses the question of why and how Asia has climbed up the EU's trade priority list. Tracing official documents since the mid-1990s, it shows the EU's perceived weakness in Asia, and how its policy has been shaped by USA actions. The narrative focuses on trends in FTA negotiations and argues that the EU's policy has been guided by fear of possible competition with the USA, and to a lesser extent China and Japan. In analyzing the timing and rationales for the negotiations, the article pays particular attention to changes within the EU's institutional architecture, sectoral preferences and material interests to explain how these mediate the EU's FTA agenda. In doing so, it offers a more nuanced conceptualisation of what constitutes fears of trade diversion than does current literature on FTAs. Sections 2 and 3 chart the changing importance of Asia in the EU's trade policy from the 1990s to the 'Global Europe' strategy of the mid2000s. Section 4 introduces common rationales for undertaking FTAs, and section 5 applies these to the EU FTA with South Korea. The latter presents a short case study comparing the EU and USA FTAs with South Korea and argues that their similarity reveals a game of competition and preventing future discrimination. Section 6 draws implications from this case for other negotiations, detailing how the comprehensive agreement with a willing Korea may be impossible with more reluctant partners. 


\section{Asia in the EU's Trade Policy in the 1990s 'New Asia Strategy’}

As the Cold War drew to a close, the EU sought to expand its "global presence." Upgrading basic economic and cooperation ties that its predecessor the European Community had established was a cornerstone in this endeavour. ${ }^{1}$ Within this context, in 1994, the European Commission's Directorate General (DG) 1B, 2 launched strategies for Asia and Latin America. where EU coordinated action had been neglected. The economic rationale for closer ties is expressed unambiguously in the New Asia Strategy": "The Union needs as a matter of urgency to strengthen its economic presence in Asia in order to maintain its leading role in the world economy." 3 Concerns about competitors are evident:

The Union is lagging seriously behind other investors in the Asian boom (providing only 10 percent of inward FDI to East and Southeast Asia between 1986 and 1992). 4

The USA's proposals to enhance APEC (Asia Pacific Economic Cooperation) into a free trade area ${ }^{5}$ further worried officials in the European Commission. ${ }^{6}$ Given APEC's commitment to 'open regionalism' these proposals never crystallised. Yet, to counter potential threats, the 'New Asia Strategy' aimed:

(i) to benefit from the economic opportunities and to respond to the economic challenges in the region which contains the world's fastest growing countries [...]

(ii) to integrate into the open, market-based world trading system those Asian countries such as China, India or Vietnam which are moving from state controls to market-oriented economies; and

(iii) to assist in the enormous problem of poverty alleviation.

To secure these objectives, [...] the European Union needs to accord Asia a higher priority than it has done in the past. ${ }^{7}$

To achieve this, the Document highlights the need to "earn business" and focuses on:

Trade policy with an emphasis on de facto market access for both trade in goods and services will therefore be a key component in the Union's strategies towards not only developed Asia but also Asia's newly emerging markets. ${ }^{8}$

Despite clear economic aims, it never mentions possible FTAs, except to welcome an

\footnotetext{
${ }^{1}$ C. Bretherton\&J . Vogler, The European Union as a Global Actor, New York, Routledge, 2006. The EU was formally created in the 1993 Maastricht Treaty on European Union, and until the Lisbon Treaty of 2011, trade was formally an EC and not EU affair, however for simplification purposes much of the literature, and this article, refers to the EU throughout.

2 DG 1 B was responsible for relations with Latin America, Asia, Middle East and Mediterranean and the developing world. In 1999 the geographic DGs for external relations were replaced by DG Trade, DG Enlargenent, DG Development, and DG External Relations.

${ }^{3}$ European Commission (1994) 'Towards a New Asia Strategy' COM (94) 314, Brussels, p. 1.

4 Ibid., p.21.

5 This followed on from the creation of the North American Free Trade Agreement (NAFTA) in 1994, which had resulted in a 20 percent loss of market for EU businesses in Mexico.

${ }^{6}$ From an interview with official in DG Relex, Brussels, J une 2007.

${ }^{7}$ European Commission (1994) 'Towards a New Asia Strategy' op. cit., p.13.

8 Ibid. p. 14
} 
ASEAN (Association of South East Asian Nations) FTA, ${ }^{9}$ which is in line with the EU's general support for regional integration elsewhere on the planet. ${ }^{10}$ Within its trade priorities, preferential access to the EU's market was reserved for states linked to the EU via the Lomé agreements with former colonies, ${ }^{11}$ and then to the EU's neighbours to the East and in the Mediterranean Basin who enjoyed other privileges. ${ }^{12}$ Asian states were, and are, covered by the General System of Preferences (GSP), which whilst less generous than concessions granted to preferential partners, were, nonetheless above, industrialized states covered only by the WTO's Most Favoured Nation Principle (MFN). 13

The EU's GSP, modeled on the United Nation's version, began in 1971. It covers 176 states and territories, which receive extra tariff reductions on their exports to the EU over the MFN rate. Preferential rates apply to 7000 products, of which 3750 are considered sensitive. Beyond the GSP general arrangements, the EU extends a GSP+ with greater tariff reductions to states that also agree to undertake reforms for environmental protection or respect for International Labour Organisation (ILO) core principles. Since 2004, it offers a more generous arrangement to the 49 least developed states under the 'Everything but Arms' (EBA), ${ }^{14}$ which allows full duty free access of exports to the EU. With the exception of Singapore, J apan and Korea, Asian states are covered by the GSP scheme, and Bhutan, Bangladesh, Cambodia and Myanmar also fall within the EBA. 15

Studies on the effectiveness of the GSP scheme show that the applicability of the scheme is limited, with only 7 percent of GSP countries' exports benefiting from it. Only 23.4 percent of exports from EBA states entering the EU using EBA preferences. ${ }^{16}$ Furthermore, the greatest beneficiaries of the scheme are normally medium income economies, ${ }^{17}$ as they can take better advantage of exporting opportunities. In the case of ASEAN countries, preferential imports (into the EU) stagnated under the GSP regime. ${ }^{18}$ According to the EU's DG Trade, the GSP regime

\footnotetext{
9 Ibid., p. 19.

${ }^{10}$ See F. Soderbaum, P. Stralgren, \& L. van Lagenhove, The EU as a Global Actor and the Dynamics of Interregionalism: A Comparative Analysis', European Integration, Vol 27, No 3, pp. 365-380.

11 These are states in Africa, the Caribbean, and the Pacific often collectively referred to as ACP.

12 European Free Trade Association (EFTA) states and Turkey have customs unions with the EU North African states had preferential treatment under specailised programmes and the Central and Eastern European states were covered by the Europe Agreements in preparation for EU accession.

${ }^{13}$ C. Stevens, 'Creating a Development Friendly EU Trade Policy,' IDS Working Paper, London, Institute for Development Studies, 2005.

14 European Commission, DG Trade Generalised System of Preferences (berussels), 2004

$<\mathrm{http} / / /$ trade.ec.europa.eu/doclib/docs/2004/march/tradoc 116448.pdf>, accessed18 May 2012.

${ }^{15}$ Myanmar's participation in the GSP scheme was suspended as part of the EU's sanctions against the Myanmar regime, which it had imposed in 1996 as a response to the J unta take-over and arrest of opposition leader Aung San Suu Kyi, With her release and participation in elections, the EU suspended sanctions in April 2012, and reopened the way for Myanmar to participate in GSP and EBA. (A. Gardner, 'EU suspends Myanmar Sanctions' 23.04.2012, European Voice, <http:// www.europeanvoice.com/article/2012/april/ eu-suspends-myanmarsanctions/74190.aspx > , accessed 21 May 2012). For more on the EU's sanctions and complex relationship with Myanmar see Manea, 'Human rights and the interregional dialogue between Asia and Europe: ASEAN-EU relations and ASEM,' The Pacific Review, Vol. 21, No. 3, 2008, pp. 369-396; T. King, 'Human Rights in European Foreign Policy: Success or Failure of Postmodern Diplomacy', European J ournal of International Law, Vol. 10, 2011, pp. 313-337; and , J . Pilger, 'The Betrayal of Burma,' The World Today, Vol. 52, 1994 , p. 227.

${ }^{16}$ M. Gasiorek, J. Lopez Gonzalez, and M. Mendez Parra, 'Has the EU’s GSP been effective? Lessons for the future,' Trade Negotiations Insights, Vol. 10, No. 5, 2011.

${ }^{17} \mathrm{~B}$. Onglugo, 'The EU's GSP is a Key tool for increasing trade of developing countries especially in the context of the global economic crisis,' UNCTAD, 2008, <http:// trade.ec.europa.eu/ doclib/html/ 145917.htm >, accessed 18 May 2012.

${ }^{18}$ W. Zhou \& L. Cuyvers, 'The Effectiveness of the EU's GSP: Evidence from ASEAN countries', J ournal of International Trade Law and Policy, Vol. 11, No. 1, 2012, pp. 65-81.
} 
accounts for only 4 per cent of total imports into the EU and 40 per cent of GSP preferences benefit states now considered in the middle to higher income range (Russia, India, Thailand, China). ${ }^{19}$ In this context, in 2011, the European Commission proposed to reform the GSP system reducing beneficiaries to 80 and incorporating a mechanism to remove states which have been classified as high or upper-middleincome by the World Bank for three consecutive years from the list, 20 as well as states whose GSP preferences have been superseded by more comprehensive FTAs with the EU. ${ }^{21}$ The GSP regime has thus facilitated Asian exports to the EU, but has been a weaker instrument for forging ties than the more generous trade arrangements and institutionalized ties the EU established with its neighbours and former colonies.

Beyond the economic aspects, the EU's 1990s Asia Strategy also aimed to break-down cultural and political barriers between the regions, to facilitate future discussions, and promote an EU style of international relations based on dialogue and cooperation, but intent on facilitating material gains as well:

Closer consultation and dialogue can generate a greater understanding of each other's viewpoints and problems and facilitate the search for consensus solutions. This can in turn help to avert disputes and provide an environment which is of benefit to business both in Europe and in Asia. [...]. If the Union can assist in the development of a consensus approach, this will feed into inter-regional initiatives (e.g. APEC) and smooth the path for work undertaken at the multilateral level, for example concerning the post Uruguay Round agenda. 22

\section{Asia in the EU's post- 'Global Europe’ Trade Strategy}

Through economic and finance ministers' and senior officials' meetings, the AsiaEurope Business Forum (AEBF), and the Trade Facilitation Plan which tackles the reduction of non-tariff barriers (NTBs) to trade and the implementation of an

\footnotetext{
${ }^{19}$ K. De Gucht, 'Press Statement at Conference on GSP Review' 10 May 2011, available at $<\mathrm{http}$ :// ec,europa.eu/trade/ wider-agenda/ developmnet/generalised-system-of-preferences/>, accessed 18 May 2012.

20 European Commission, 'Proposal for a Regulation to the European Parliament and Council applying a scheme of GSP' COM (2011) 241 (final). This Regulation is currently undergoing the codecision legislative process at the European Parliament and Council.

${ }^{21}$ The exception to this are the Least Developed States which will continue in the GSP even if they are also ceoverd by PTAs (e.g. Cotonou Economic Partnership Agreements) and which can choose to use whichever one of the two regimes grants better access to the EU at a givcen time for a given product.

22 op. cit. pp. 18-19.

One of the key ways in which this cooperation and dialogue has been operationalised has been through the AsiaEurope Meeting (ASEM), the brainchild of Singaporean Prime Minister Goh Chok Tong. This forum has taken a less formally institutionalist approach than the EU's relations with other regions. This reflects the more voluntary nature of regional cooperation in the East and South East Asian region, where ASEAN, APEC and other initiatives at regionalization have been characterized by weak institutionalization. ASEM has been a useful instrument for the furthering of the EU's agenda in terms of building trust with Asian states. However, progress on the negotiation of specific instruments for the facilitation of investment has been protracted, partly due to the diversity amongst the Asian partners. Attempts by the EU to utilize the forum to further the EU's agenda of international human rights and conflict resolution have not succeeded, but have contributed to generating a greater sense of community in South East Asia. See M. Manea, 'Human rights and the interregional dialogue between Asia and Europe: ASEAN-EU relations and ASEM,' The Pacific Review, Vol. 21, No. 3, pp. 369-396 and R. Pardo Pacheco, The Political Weakness of the EU in East Asia: A Constructivist Approach,' Asia-Europe J ournal, 7, 2009, pp. 265-280. For more on human rights in EU foreign policy see T. King, 'Human Rights,'1999; S. Lucarelli and I. Manners, Values and Principles in European Union Foreign Policy, Abington, Routledge, 2006; R. Youngs, 'Normative Dynamics and Strategic Interests in the EU's External Identity,' J ournal of Common Market Studies, Vol. 43, No. 4, 2004, pp. 787-806.
} 
Investment Promotion Action Plan, attempts have been made to pursue the EU's economic aims of economic relevance in Asia. ${ }^{23}$ In its relations with ASEAN, the cooperation on trade pillar has been crucial and has focused on supporting ASEAN regional integration, an Intellectual Property Rights (IPR) programme, and a project to build statistical capacity to facilitate customs procedures. ${ }^{24}$ Pushing this agenda is in line with the EU's overarching trade interests in a "deep trade agenda" 25 that includes convergence in behind the border matters, liberalization of services, regulations regarding competition policy, intellectual property rights and public procurement procedures- the so-called Singapore issues that have proven highly controversial at the World Trade Organisation (WTO).

These initiatives, consistent economic growth in Asia, and the strategies of transnational corporations, have signified that economic interdependence between the EU and Asia has increased. In 2010, China was the EU's top supplier (18 per cent of imports) and second biggest market (8.4 per cent of exports), whilst the EU accounts for about a fourth of China's trade. ASEAN accounted for 5.2 per cent of EU trade, and China, India, J apan and South Korea were amongst the EU's top ten trade partners. ${ }^{26}$ Investments have also experienced sharp rises, with EU Foreign Direct Investment (FDI) stocks in Asia increasing by 74 per cent between 2004 and 2009, and accounting for 15.1 per cent of EU outward FDI. FDI inflows from Asia have risen by 10 per cent and represent 11 per cent of total FDI in the EU. ${ }^{27}$

However, the EU's relationship with Asia remains complicated, with the EU running large deficits in trade in goods, and surpluses (of a lesser magnitude) in trade and services and investment flows. Official documents continue to betray an anxiety about losing out in the region. This is evident in the 2006 'Global Europe' strategy produced by the European Commission's DG Trade. 'Global Europe' marked a shift in the EU's trade policy, towards a more overtly self-interested policy based on a 'competitiveness' ideational justification. The EU, which until 2000 was party to more preferential trade agreements than any other state or regional grouping, refrained from initiating new FTAs during Lamy's time as Trade Commissioner (1999-2004) in an attempt to bolster multilateral negotiations at the WTO's Doha Development Round. Reacting to a rapid rise in FTA negotiations in the world as a result of floundering WTO talks, and the USA's abandonment of its multilateral liberalisation stance in the early 2000s, ${ }^{28}$ Commissioner Mandelson's (2004-2009)

\footnotetext{
${ }^{23}$ These initiatives have been promoted within the aegis of the broader Asia Europe Meeting (ASEM) institutionalized dialogue.

${ }^{24}$ DG Trade 2.12.11 < http:// ec.europa.eu/ trade/ creating-opportunities/ bilateral-relations/regions/ asem/ >, accessed 18 May 2012.

${ }^{25}$ A. Young, \&J. Peterson, The EU and New Trade Politics,' J ournal of European Public Policy, Vol. 13, No. 6, 2006, pp.795-814.

${ }^{26}$ DG Trade 01.12.11 <http:// ec.europa.eu/trade/ creating-opportunities/ bilateral-relations/regions/ asean/ > , accessed 18 May 2012.

27 Author calculations with data from EUROSTAT 01.12.11 EU FDI Extra-EU27

$<$ http:// epp.eurostat.ec.europa.eu/tgm/ refreshTableAction.do?tab=table\&plugin=0\&pcode=tec00094\&language $=$ en>, accessed 20 J anuary 2012 .

${ }^{28}$ In the late 1980s-early 90s, the USA negotiated NAFTA with Canada and Mexico. Afterwards Congress became more sceptical of FTAs. Throughout the Clinton administration the President lacked Trade Promotion Authority to facilitate the ratification in Congress of any FTA it might negotiate, so it pursued an agreement at the WTO. By the early 2000s, given difficulties at the WTO, the USA changed policy priorities to further liberalisation ins all venues possible, including bilaterally. For more see J. Schott, 'Free Trade Agreements and US Trade Policy: A Comparative Analysis of US Initiatives in Latin America, the Asia-Pacific Region, and the Middle East and North Africa,' The International Trade J ournal, Vol. 20 No. 2, 2006, pp. 95-138.
} 
'Global Europe' advocates FTAs and, for the first time, delineates criteria for partners:

The key economic criteria for new FTA partners should be market potential (economic size and growth) and the level of protection against EU export interests (tariffs and non-tariff barriers). We should also take account of our potential partners' negotiations with EU competitors, the likely impact of this on EU markets and economies[...]

[...] ASEAN, Korea and Mercosur (with whom negotiations are ongoing) emerge as priorities. They combine high levels of protection with large market potential and they are active in concluding FTAs with EU competitors. ${ }^{29}$

India and Russia are mentioned as potential candidates too, although less urgent as they were not in direct negotiations at the time with the USA. China gets a special mention and a policy paper devoted to 'getting China right,' which stressed the complex economic relationship between the two. ${ }^{30}$

The "new competitiveness-driven FTAs" focus on furthering the EU's economic interests by strengthening links with markets that will be important in the future. ${ }^{31} \mathrm{In}$ terms of content, they offer continuity with the "deep trade agenda" that Lamy had favoured at the WTO. ${ }^{32}$ There is also a clear concern with staying on a par with competitors: "Where our partners have signed FTAs with other countries that are competitors to the EU, we should seek full parity at least," 33 which accounts for the choice of FTA partners (Korea was negotiating with the USA as were Thailand, Malaysia ${ }^{34}$ and Singapore, and ASEAN was negotiating with China). In this sense, the EU's trade policy in Asia has been influenced by lack of progress at the WTO and by the actions of the USA and other players in Asia, as shown in the timeline of negotiations depicted in Table 1. This is all the more evident in the fact that in 2003 when Singapore made entreaties to the EU regarding negotiations for a FTA, the EU declined. In 2003, DG Trade operated under Lamy's moratorium on new FTAs. By 2007, DG Trade was led by a free-trade committed Peter Mandelson, and many of the DG's moratorium proponents had moved to other DGs, leaving those in favour of negotiating more market access to create a level playing field vis-a-vis competitors in

\footnotetext{
${ }^{29}$ DG Trade, European Commission (2006) Global Europe. Competing in the World, Brussels, p. 11.

30 DG Trade, European Commission (2006) Global Europe. EU-China Trade and Investment. Competition and Partnership, Brussels.

On the one hand they are key trade partners, on the other they are also important competitors. Whilst an FTA with China is not on the cards, the EU has engaged China through 26 Dialogues, some on very technical matters, which thus permit a depoliticisation of controversial issues, and offer a chance to circumvent especially contentious matters like the EU's promotion of human rights and the abolition of the death penalty. China's importance was also acknowledged in the decision to frame the relationship within the EU's novel foreign diplomacy tool of Strategic Partnership (since 2005). However, for now the long-term strategic component appears to be absent from the dialogues and development of the partnership.See M. Smith and H. Xie, The EU and China: The 'Logics' of Strategic Partnership', J ournal of Contemporary European Research, Vol. 6, No. 4, 2010.

${ }^{31}$ S. Woolcock, 'European Union Policy Towards Free Trade Agreements,' ECIPE Working Paper No.03/2007, p. 4.

32 P. Lamy, 'Stepping Stones or Stumbling Blocks? The EU's Approach Towards the Problem of Multilateralism vs Regionalism in Trade Policy', World Economy, Vol.25, No.10, 2002, pp. 1399-1413.

33 Ibid. p. 11.

34 Malyasia was in negotiations with the USA at the time of 'Global Europe.' Malaysia and the USA negotiated a FTA between 2006 and 2008 but abandoned negotiations in 2008. Both are now linked in the multiparty Transpacific Partnership (TPP) negotiations.
} 
the ascendancy. ${ }^{35}$ Moreover, by then WTO negotiations were faltering, thus making an FTA with Singapore feasible. Singapore's position as a key "Asian hub" 36 and its FTAs with EU competitors, (USA, China, South Korea, Japan) made negotiations more urgent.. ${ }^{37}$ Rather than initially negotiating with Singapore, the EU opted to open negotiations with ASEAN in 2007. Negotiating with a bloc provides savings in terms of negotiations as well as access to a larger market. ASEAN accounts for 5 percent of EU total trade, whereas Singapore represents only 0.6 percent. ${ }^{38}$ When bloc-to-bloc negotiations failed given the disparities of interests amongst ASEAN members, the EU continued on a bilateral basis with Singapore, Vietnam, and later Malaysia in 2010.39 It is no coincidence that these are the most advanced ASEAN economies and the ones that were implementing the China-ASEAN FTA, and, in the case of Singapore, also had a FTA with the USA.

\section{Table 1. Timeline of USA, EU, Chinese Free Trade Agreements in East Asia}

\begin{tabular}{|c|c|c|c|c|c|}
\hline & $\begin{array}{l}\text { CHINA } \\
\text { start }\end{array}$ & $\begin{array}{l}\text { CHINA } \\
\text { conclude }\end{array}$ & $\begin{array}{l}\text { EU } \\
\text { start }\end{array}$ & $\begin{array}{l}\text { EU } \\
\text { conclude }\end{array}$ & \begin{tabular}{l|l} 
USA & USA \\
start & conclud \\
& e
\end{tabular} \\
\hline ASEAN & 2001 & 2007(2010*) & 2007 & & \\
\hline HONG KONG & & 2003 & & & \\
\hline MACAO & & 2003 & & & \\
\hline THAI LAND & & 2003 & & & $\begin{array}{ll}2004 & \text { (suspended } \\
2006) & \\
\end{array}$ \\
\hline SI NGAPORE & & 2008 & 2010 & & $\begin{array}{l}2003 \\
(2004)\end{array}$ \\
\hline S KOREA & & & 2007 & $\begin{array}{l}2009 \\
(2011)\end{array}$ & 2006 \\
\hline MALAYSIA & (ASEAN) & & 2010 & & 2006 \\
\hline VIET NAM & (ASEAN) & & 2010 & & \\
\hline INDIA & & & 2007 & & \\
\hline \multicolumn{6}{|c|}{$\begin{array}{l}\text { ASEAN: Brunei Darussalam, Cambodia, Indonesia, Lao PDR, Malaysia, Myanmar, Philippines, Singapore, } \\
\text { Thailand, Viet Nam } \\
\text { *2010 for Brunei Darussalam, Malaysia, Singapore, Philippines, Thailand, Indonesia, } 2015 \text { for others } \\
\text { Agreement implementation in brackets. Sources: European Commission DG Trade website, US Trade }\end{array}$} \\
\hline
\end{tabular}

\footnotetext{
35 S. Woolcock, 'European Union policy toward Free Trade Agreements,' ECIPE Working Paper No. 3/2008, p. 5; also A. Young, 'Trade Policy Ain't What it Used to Be: The European Union in the Doha Round,' J ournal of Common Market Studies, Vol. 45, No. 4, 2007, p. 799.

36 S. Tay, Asia Alone: The Dangerous Post-Crisis Divide from America, Singapore, J ohn Wiley \& Sons, 2010, pp. 141-150.

37 In 2007 the EU also opened negotiations with India fearing talks of potential trade negotiations with the USA, and to allay Indian complaints about EU trade concessions and aid to Pakistan. Negotiations have been very difficult given divergent interests. See S. Khorana, S.and N. Perdikis 'EU and India Free Trade Agreement: Deal or No Deal?,' South Asia Economic J ournal, Vol. 11, No. 2, 2010, pp.181-206.

38 European Commission, DG Trade (2012) 'EU Trade with ASEAN' available at

<http:// ec.europa.eu/trade/ creating-opportunities/bilateral-relations/regions/asean/>, accessed 21 May 2012.

${ }^{39}$ In sharp contrast with the interregional focus placed on FTA negotiations with Mercosur. See M. Doctor, 'Why Bother with Inter-Regionalism? Negotiations for a European Union-Mercosur Agreement' J ournal of Common Market Studies, Vol 45, No. 4, 2007, pp. 281-314.

40 MOFCOM Chinese Ministry of Foreign Trade $<$ http://fta.mofcom.gov.cn/english/fta qianshu.shtml, USTR 2012 United States Office of the Trade Representative, 2012, <http:// www.ustr.gov/trade-agreements/ free-tradeagreements > , ASEANWEB $2012<$ http:// www.asean.org/ 20164.htm >, DG Trade 2012 European Commission Trade <http:// ec.europa.eu/trade/ creating-opportunities/ bilateral-relations/ free-trade-agreements/ > accessed 10 May 2012.
} 


\section{Rationale for EU FTAs in East Asia}

From a policy-making perspective, decisions to pursue FTAs provide an interesting puzzle, given their many detractors. Economists are concerned with the technical and costly effects of a complex "spaghetti bowl" of tariffs, rules of origin and regulations. ${ }^{41}$ They favour liberalization at the WTO, and have focused work on FTAs in a debate on the compatibility of bilateral and multilateral liberalization, ${ }^{42}$ where FTAs have been viewed as both "stumbling blocs" 43 and "stepping stones" 44 to the WTO. Empirical studies of the effects of FTAs agree that, FTA pairings, typically between a larger and smaller economy, have resulted in unimpressive overall welfare outcomes. ${ }^{45}$ Yet they continue to proliferate, ${ }^{46}$ prompting explanations for such policy choices which range from Baldwin's "domino effect" where governments concerned about hypothetical trade diversion effects will choose to enter other FTAs; ${ }^{47}$ ways of furthering liberalization whilst retaining some protected lists so as to reconcile opposing interests amongst domestic industries; 48 to "competitive diffusion" where actors emulate what their peers are doing. ${ }^{49}$ This competitive emulation of others (USA mostly) and fear of being left out of the FTA networks and perhaps having some exporters at a disadvantage to USA or Asian exporters was evident in the discourse of 'Global Europe', especially since the overall welfare outcomes predicted from its FTAs are marginal. The estimated effects of the EUKorea FTA on GDP are 0.08 per cent for the EU and between 0.4 and 2 per cent for South Korea. ${ }^{50}$ Similarly, the Sustainability Assessment commissioned whilst EU-

\footnotetext{
${ }^{41}$ R. Baldwin, 'Multilateralising Regionalism: Spaghetti Bowls as Building Blocs on the Path to Global Free Trade,' The World Economy, Vol. 29, No. 11, 2006, pp. 1451-1518.

${ }^{42}$ E. Mansfield, \&H. Milner, 'The New Wave of Regionalism,' International Organisation, Vol. 53, 1999, pp. 589627.

${ }^{43}$ P. Krugman, 'Regionalism versus multilateralism: analytical notes,' in J . de Melo and A, Panagariya (eds.), New Dimensions in Regional Integration, Cambridge, Cambridge University Press, 1993, pp. 58- 89;

L. Thurow, Head to Head: The Coming Battle among J apan, Europe and America, NY, William Morrow, 1992; J . Bhagwati, The World Trade System,'J ournal of International Affairs, Vol. 48, No. 1, 1994, pp. 279-285; J . Bhagwati, Termites in the Trading System: How Preferential Agreements Undermine Free Trade, Oxford, Oxford University Press, 2008; R. Baldwin, 'A Domino Theory of Regionalism,' Centre for Economic Policy Research, London, Working paper, 1993, p. 857.

${ }^{44} \mathrm{C}$. Dent, 'Networking the Region? The emergence and impact of Asia-Pacific bilateral free trade agreement projects,' Pacific Review, Vol. 16, No. 1, 2003, pp. 1-28; S. Wei, \&J. Frankel, 'Can Regional Blocs be a Stepping Stone to Global Free Trade? A Political Economy Analysis,' International Review of Economics and Finance, Vol. 5, No. 4, 1996, pp. 339-347.

${ }^{45} \mathrm{~J}$. Ravenhill, 'The New Bilateralism in the Asia Pacific,' Third World Quarterly, Vol. 24, No. 2, 2003 pp. 299317; J. Hallaert, 'Proliferation of preferential trade agreements: Quantifying its welfare impact and preference erosion,' J ournal of World Trade, Vol. 42, No. 5, 2008; IBM Belgium Final Draft. Sustainability Impact Assessment. EU-South Korea FTA, Brussels, Commissioned by European Commission, 2008; ECORYS (2009) Interim Report. Trade Sustainability Impact Assessment EU-ASEAN FTA. The Netherlands, Commissioned by European Commission,

Y. Decreux, C. Milner, and N. Peridy, The Economic Impact of the Free Trade Agreement between the EU and Korea, CEPII/ATLASS Study for DG Trade, 2010.

46 The WTO 2011 World Trade Report (WTO, 2011) offers an overview of the FTA phenomenon and a synthesis of the FTA literature on pages 94-99. It suggests further rationales for FTAs such as the successful lobbying by exporting firms, and also to send political signals to foreign investors (about a state's willingness to open the economy), however it casts doubst as to why that would be a better signal than a commitment to the WTO.

${ }^{47}$ R. Baldwin, 'A Domino Theory of Regionalism,' op. cit.,p. 857.

${ }^{48} \mathrm{~J}$. Ravenhill, op. cit., pp. 168-95.

${ }^{49}$ M. Solis, \& S. Katada, 'Explaining FTA Proliferation: A Policy Diffusion Framework,' in M. Solis, B. Stallings \& S. Katada (eds.), Competitive Regionalism. FTA Diffusion in the Pacific Rim, Basingstoke, PalgraveMacmillan, 2009, pp.1-26.

${ }^{50}$ IBM (2008) Sustainability Impact Assessment, p. 18.
} 
ASEAN negotiations were underway, suggested that in a comprehensive FTA scenario welfare gains as percentage of GDP would be $0.23 \%$ for the EU and 3.66 to $15.27 \%$ for different ASEAN states, and in the case of a restrictive FTA $0.02 \%$ and $0.08-1.92 \%$ respectively, ${ }^{51}$ with ASEAN states gaining additional market access to the EU and European transnational corporations strengthening their impact in the ASEAN region.

Despite such unimpressive predictions, 'Global Europe', imbued by a sense of competition, promoted FTAs. In 2003, ASEAN had asked the EU to consider an FTA, but -- Lamy's FTA moratorium and the unsuccessful negotiations with MERCOSUR made it skeptical. ${ }^{52}$ By 2006, 'Global Europe' prioritised an FTA with ASEAN. Negotiations began in May 2007 and progressed slowly, due to the differences amongst ASEAN members and the EU's requirements that its FTAs encompass trade, Singapore issues, and political clauses. This complicates negotiations, and contrasts, for instance, with the Chinese more limited liberalization approach, which facilitated its negotiations with ASEAN. ${ }^{53}$ The Philippines, for example, signaled from the start that the political cooperation agreement would be problematic as it requires signatories to become members of the International Criminal Court. 54 The EU's sanctions on Myanmar's J unta further complicated matters. The EU's approach was to negotiate with ASEAN minus Myanmar, in a way impinging on ASEAN's own founding principle of 'non-intervention' in its members' domestic affairs.

Shifting from its previous trade strategy prioritizing multilateral and interregional negotiations (with ASEAN, Mercosur, Central America), which had even been characterized by some as "a doctrine of global policy-based on interregionalism,"55 Trade Commissioner Karel De Gucht (since 2009) announced negotiations for a FTA with Singapore and with Vietnam in March 2010. Singapore is the ASEAN state with which the EU already has closer economic ties. In the case of Vietnam, one of the more developed and populous economies in ASEAN, there is potential for enhanced economic relations, revealing commercial interests as well.

'Global Europe' established that there be a clear economic case for FTAs, which can be interpreted as meaning some real increase in market access in addition to that achieved at the WTO. ${ }^{56}$ Given the asymmetric outcomes of FTAs, any FTA will produce gains for some sectors, ${ }^{57}$ especially those facing greatest restrictions. Thus, it is normally possible to make some kind of economic case for them. The sectors the EU seeks to benefit through FTAs are service providers. 58 'Global Europe' also gave

\footnotetext{
51 ECORYS (2009) Sustainability Impact Assessment, p. 18.

${ }^{52}$ A. Robles, 'An EU-ASEAN FTA: The EU's Failures as an International Actor,' European Foreign Affairs Review, Vol. 13, No. 4, 2008, p. 337.

53 R. Sally, 'China's Trade Policy in Wider Asian Perspective', Paper prepared for the LSE/ CCER conference, Beijing, 22/ 23 August 2005 2005; S. Lijun, 'China-ASEAN Free Trade Area: Origins, Developments and Strategic Motivations,' ISEAS Working Paper: International \& Security Issues, Series No. 1, 2003.

$54<$ http:// www.bilaterals.org>, accessed 20 May 2012.

${ }^{55} \mathrm{~F}$. Söderbaum and L. Lagenhove, 'The EU as a Global Actor and the Role of Interregionalism,' J ournal of European Integration, Vol. 27, No. 3, 2005 pp. 366, 371.

56 S.Woolcock, 'European Union trade policy: domestic institutions and systemic factors,' in D. Kelly, and W.Grant (eds.), The politics of international trade in the twenty-first century: actors, issues and regional dynamics, Palgrave, Basingstoke, UK, 2005, pp. 234-252; S. Woolcock, 'European Union Policy towards Free Trade Agreements', ECIPE Working Paper, 03/2007, 2007, p. 4.

${ }^{57}$ R. Ahearn, 'Europe's Preferential Trade Agreements: Status, Content and Implications,'R41143, Congressional Research Service, Washington DC, 2010.

58 The EU already runs a surplus in trade in services with all its Asian partners, but more transparent and harmonized standards and rules would further increase the competitiveness of its service providers.
} 
prominence to strengthening international rules (e.g. intellectual property) on which the EU was unable to forge consensus at the WTO. However, making an economic case, is a political choice. In 2003, the EU declined negotiations with ASEAN, and in 2004 it rebuked repeated entreaties by Singapore for negotiations claiming the absence of an economic case. ${ }^{59}$ After 'Global Europe' with its new consensus within DG Trade on leveling the international playing field for EU business, and the fact that this state had signed FTAs with the USA and China, the EU found Singapore's limited markets more appealing. It appears that the economic case is less about actual gains and more about competitors potentially gaining an advantage. In other words, it could be viewed as a race to maintain the status quo amongst major players, at a time when agreeing multilateral rules appears more complicated.

The move to bilateral deals reflects a pragmatic approach, as a bilateral deal is easier to negotiate than reaching an agreement with another regional grouping that often lacks the level of institutional unity the EU has developed. ${ }^{60}$ It enables the EU to keep up with USA FTAs, and also China's and J apan's. In the case of the EU-ASEAN FTA, the bilateral approach also enabled European governments to deal with the economic heterogeneity within ASEAN. ${ }^{61}$ Notwithstanding this, the EU remains intent on an eventual bloc-to-bloc deal as highlighted by De Gucht himself:

The launch of FTA negotiations with Singapore, for us, marks the beginning of a deeper engagement with Asia, and in particular in our relations with the ASEAN region.

Although Singapore is the 'first one in,' our door remains open for other ASEAN countries interested in negotiating a comprehensive free trade agreement with us. We are not available to do shallow FTAs, but we will be mindful of differences in levels of development. ${ }^{62}$

\section{Overview of Korea-EU (KOREU) and Korea-USA (KORUS) FTAs}

As most of these negotiations are underway, it is impossible to compare the agreements, although the EU will (like the US) use its most comprehensive agreement to date (KOREU) as a template for ongoing negotiations, hence the relevance of looking at this case more closely. Key characteristics of EU FTAs, in common with the USA's, are that they are comprehensive in scope (with few omissions of sensitive items), incorporate legally binding arrangements on behindthe-border matters like customs procedures and standards, include Singapore issues 63 as well as social and environmental matters. However, EU FTAs are accompanied by a political pillar in the form of a framework agreement institutionalizing the relationship and cooperation in all areas, including attempting to coordinate positions in international fora (UN, WTO, climate talks). This is a peculiarity of EU FTAs, and it reflects the inherent tension within the EU's trade

\footnotetext{
59 Interview with DG Trade official, Brussels, J une 2007.

60 A. Robles, op.cit.

${ }^{61}$ Similarly, the USA eschewed negotiations with ASEAN in favour of bilateral deals, and although China negotiated a China-ASEAN FTA, it followed a differentiated approach to individual ASEAN states.

62 K. De Gucht, 'Europe and Singapore: partners in trade, partners for growth,' Speech given at the Lee Kuan Yew School of Public Policy, Singapore, 3 March 2010.

<http:// europa.eu/ rapid/pressReleasesAction.do?reference=SPEECH/ 10/ 58 >, accessed 10 November 2011.

63 These are liberalisation of services, intellectual property rights, competition policy, access to public procurement.
} 
policy, as a tool of foreign policy and the oldest foreign policy of the EU, 64 to serve other policy objectives. ${ }^{65}$

In the case of KOREU, the framework agreement is straightforward as both partners share similar objectives internationally and common values of democracy and respect for human rights. Moreover, the framework agreement has little that is legally binding. Whilst broad in scope, the articles commit the parties to "work towards," "encourage mutual cooperation and information exchange", "endeavour to cooperate", in education, environmental protection, migration issues, fisheries, development policies, combating terrorism and arms trafficking amongst others. ${ }^{66}$ The main achievement in this respect was persuading Korea to acquiesce to core labour standards of the International Labour Organisation (ILO). ${ }^{67}$

By contrast, the detailed FTA is legally binding, as is KORUS. Both can be considered deep agreements, as they go well beyond the WTO ${ }^{68}$ and incorporate the Singapore issues. These are the most comprehensive agreements, but also lengthy to negotiate and to ratify. KORUS was signed in June 2007, when KOREU negotiations commenced. However, it underwent modifications to ensure USA Congressional support (mainly regarding safeguards on automobile exports) and was ratified in October 2011. KOREU also experienced a lengthy ratification process. It was signed in late 2009 and after clarification of a safeguard clause (also on Korean car exports), and delays in the European Parliament, it was ratified in February $2011^{69}$ and provisionally implemented in July. Unsurprisingly, given that the EU and USA use FTAs to further the liberalization the coverage of KOREU and KORUS is similar. Differences in terms of trade in goods lie in the better access to foodstuffs (processed foods) gained by the EU, and access for vegetables and meat negotiated by the USA, which is explained by the larger respective trade volume in exports of these products. ${ }^{70}$

Korean car manufacturing is a highly competitive industry and one the Korean government sought to benefit though FTAs. Korea insisted on better market access for its car exports as a sine qua non requirement. As interview materials collected by Elsig Manfred and Cedric Dupont reveal, German car industry representatives recalled that: "Over time the [German] government gave more preference to other industry sectors (...) we were reminded that we had already received sufficient support (the German Abwrackprämie, and tax exemptions)."71 They comment that

\footnotetext{
64 M. Smith, 'The European Union's Commercial Policy, Between Coherence and Fragmentation,' J ournal of European Public Policy, Vol. 8, No. 5, 2001, pp. 787-802.

65 M. Baldwin, 'EU Trade Politics - Heaven or Hell?,' J ournal of European Public Policy, Vol.13, No. 6, 2006, pp. 926-942.

66 Framework Agreement Between the European Union and its Member States, on the One Part, and the Republic of Korea, on the Other Part (2010), <http:// eeas.europa.eu/korea_south/index_en.htm>

67 S. Woolcock, 'Assessment of the EU-Republic of Korea FTA', Presentation for the European Parliament Hearing

23J une 2010, <www.europarl.europa.eu/document/ .../20100628ATT77152EN.ppt>, accessed 20.01.2012

68 This is necessary if a FTA is to be authorized under GATT Article 24 and GATS Article 5 at the WTO.

69 Part of the delays were a result of KOREU being the first agreement to be approved under the Lisbon Treaty which granted the European Parliament a greater say in agreements with third parties. In particular the European Parliament sought clarification on the future mechanisms for the application of safeguard clauses in which it will now have a role.

70 Y. Song, 'KORUS FTA vs. Korea-EU FTA: Why the Differences?,' Korea Economic Institute Academic Paper Series, Vol.6, No.5, 2011.

${ }^{71}$ E. Manfred and C. Dupont,'European Union meets South Korea: Bureaucratic Interests, Exporter Discrimination and the Negotiation of New Trade Agreements', Working paper for 'Diverging Paradigms on EU Trade Policy' Workshop, Katholik Universitaet Leuven, Belgium, 16-17 Dec 2010.
} 
the German government's shift was crucial in facilitating negotiations and supporting the European Commission in its negotiations. Thus, despite protestations by EU car industries, in KOREU, and two of the three USA big car manufacturers in KORUS,72 the agreements improved market access for Korean exports.

However, the USA and EU differed in how they compensated their producers. To counter the complex process of setting environmental and safety standards followed by Korea, the USA negotiated a higher quota for USA cars exported into Korea under USA safety standards, so that it includes a number larger than the number of exports to Korea. The EU, for its part, agreed to harmonise car safety standards through international arrangements based on the rules of the UN Committee for Economic Cooperation in Europe, something Korea, which has a mix of US and Korean standards, was not entirely pleased about. ${ }^{73}$ In line with its aspirations for a multipolar world guided by agreed rules (which is essentially the basis of EU integration itself), the EU adopts a more institutional and negotiated approach. The USA's approach represents an effective (if not entirely legal) instance of mutual recognition of car safety standards, whilst the EU approach advocates negotiating standards that can be internationalized. This preference for harmonization is evident in other areas, including the joint adoption of ILO standards. ${ }^{74}$ On non-tariff barriers in pharmaceuticals and medical equipment, the EU's approach "was to oblige Korea to comply with international standards with which EU regulations already comply." "75Whilst this is more costly at the negotiation table, if eventually the EU and Korea, and others, operate on a common international set of standards the impetus will be for industries throughout the globe to adopt this, affording those already following the standards a first-mover advantage.

Services liberalization is a key objective of both EU and USA FTAs. Various studies have suggested that economic gains for the EU from KOREU would arise only if substantive service liberalization were achieved. ${ }^{76}$ Both KOREU and KORUS afford extensive liberalization of services, especially financial, accounting, telecommunications and legal services. Differences in service coverage lie in the fact that KOREU incorporates environmental services (KORUS does not), whilst KORUS includes audiovisual services and, at the EU's request, KOREU does not include health or audiovisual services. These are areas where the EU Member States retain sovereignty and, in the case of audiovisual services, the EU maintains a defensive to protect cultural diversity, particularly at the behest of France. To the extent that Korean negotiators viewed KOREU as a "balancing act" against USA reliance through

\footnotetext{
${ }^{72}$ Ford and Chrysler opposed the original KORUS and lobbied for measure increasing the number of US cars exported under US safety standards and the introduction of drawback clauses. General Motors was neutral on this as it has its own manufacturing and distribution in South Korea, since it purchased Daewoo. See W. Cooper, M. Manyin, R. J urenas, \& M. Platzer, The Proposed US-Korea Free Trade Agreement (KORUS FTA): Provisions and Implications', Federal Publications Paper 813, 2011.

${ }^{73}$ F. Nicolas, 'Negotiating a Korea-EU free trade agreement: easier said than done,' Asia Europe J ournal, Vol. 7, No. 1, 2009, pp. 23-42, p. 39.

${ }^{74}$ It is also the case that often these international standards are also the common denominator to which EU member states can agree to. In the case of labour standards, whilst Denmark, Sweden and Germany advocate going beyond ILO, the UK and the Netherlands do not wish to do so. See A. Young, Trade Politics Aint What It Used To Be: The European Union in the Doha Round,, J ournal of Common Market Studies, Vol.45, No. 4, 2007, pp. 789-811, p. 807.

${ }^{75}$ F. Erixon and H. Lee-Makiyama, 'Stepping into Asia's Growth Markets: Dispelling Myths About the EU-Korea Free Trade Agreement', ECIPE Policy Briefs, No. 3, 2010, p. 3.

${ }^{76}$ Y. Decreux, C. Milner and N. Peridy, N, The Economic Impact of the Free TradeAgreement between the EU and Korea', CEPII/ATLASS Study for DG Trade, 2010, p.3.
} 
KORUS, 77 it is unsurprising that the coverage of the agreements is similar. Where differences occur it is due mainly to divergent interests in the negotiating positions of the USA and EU, as determined by their domestic contexts. ${ }^{78}$

In terms of approach, KORUS uses a negative listwhereas KOREU has a positive list identifying the services covered by the FTA. ${ }^{79}$ In the future should some new type of services be developed in the case of KOREU the parties would have to choose to incorporate it into the agreement during the yearly implementation meetings, whereas KORUS allows for it to be automatically covered unless the parties explicitly decide to exclude it. In essence, the momentum operates in the opposite direction in each case.

Both agreements open markets for public procurement and cover intellectual protection rights. Given Korea's membership of the OECD and adherence to the multilateral TRIPS agreement at the WTO, this was not too controversial. ${ }^{80}$ A major difference, however, lies in the protection of Geographic Indicators (GI) for wines, spirits and other products. This has been a contentious issue at the WTO where the disparity between the USA's trademark-based approach and the EU's GI system has not been resolved. ${ }^{81}$ The EU hoped to gain legally-binding international recognition of its list of protected GIs. Having failed multilaterally, it has incorporated this into its FTAs, although the length of the list varies from FTA to FTA. In the case of KOREU a list with only 100 items was included. ${ }^{82}$ The Commission defended this at the European Parliament arguing that "in some negotiations full protection of the entire EU register list is not possible from the outset," and that the reduced list approach is "conditioned on the facilitation of the recognition and protection of the remaining names as a result of the agreement" and the ongoing cooperation ensuing from it. 83

\section{I mplications of the KOREU FTA}

KOREU negotiations were launched once KORUS (in its original formulation) was finalized. In the 'Global Europe' trade strategy, gaining parity with competitors, especially the USA, was a key priority for the EU. According to Françoise Nicolas, EU negotiators expected to be granted USA parity in KOREU, reasoning that if Korea had already agreed issues with the USA these would no longer cause difficulties. This also reflects the EU's, and USA's, tendency to negotiate each FTA agreement using their

\footnotetext{
${ }^{77 F}$. Nicolas, op. cit., p. 38.

78 USA objectives were to obtain better access for its agricultural products, pharmaceutical and medical equipment, high-technology goods, and services (especially financial and professional). EU aims, in keeping with 'Global Europe' were to tackle non-tariff-barriers (especially in chemicals), ${ }^{78}$ and the Singapore issues On EU objectives in the negotiations see Nicolas, F. 'Negotiating a Korea-EU FTA', p. 36.

${ }^{79}$ Anything not explicitly listed automatically falls under the remit of the agreement

80 The Trade Related aspects of Intellectual Propwerty Rights (TRIPS) at the WTO protects GIs, trademarks, and other forms of intellectual property at the multilateral level, and has been one of the complicating factors in the WTO Doha Round.

${ }^{81}$ See N. El Benni, 'Geographical Indications: discussions and negotiations about protection tools,' NCCR Trade Regulation, NCCR Trade Working Papers No. 2009/ 16.

82 The full register includes 29997 GIs for wines and 1289 for other products. Whilst most are EU GIS the register also covers non-EU products that have been added through FTAs and other partial agreements. E-BACCHUS and DOOR GI registers can be found at < $\underline{\mathrm{http}}$ // ec.europa.eu/agriculture/ quality/index en.htm $>$, accessed 15 November 2011.

83 Parliamentary Question and Answer E-2438/2010 by Mr Ciolos on behalf of the Commission, 1 June 2010, $<\mathrm{http}$ :/ / www.europarl.europa.eu/ sides/getAllAnswers.do?reference=E-2010-2438\&language=EN>, accessed 20 May 2012.
} 
last one as a base. However, "Korea did not see any reason why [this] should be the case given the very different stakes involved in the KOREU and KORUS negotiations" due to the different trade and investment patterns between the EU and Korea and the USA and Korea. ${ }^{84} \mathrm{~A}$ lesson to be drawn from this for other negotiations is that third parties will not necessarily see negotiations with the EU and USA as equivalents, and that negotiations are likely to be lengthier and more controversial than initially envisaged. Indeed, the delays in negotiations with India, and the failure of those with ASEAN bear witness to this.

Ongoing negotiations with Singapore are progressing well, and at a meeting in September 2011, the President of the European Commission, J ose Manuel Barroso, and the Prime Minister of Singapore, Lee Hsien Long, expressed their "commitment to further deepen the vibrant relationship between the European Union and Singapore, notably through the conclusion of a comprehensive Free Trade Agreement and a Partnership and Cooperation Agreement" and Barroso expressed his confidence that the negotiations can be finalized very soon. ${ }^{85}$ Singapore is one of the most open economies in the world, as well as one with vast experience negotiating FTAs, ${ }^{86}$ which include FTAs with the USA, J apan, India and China, to the chagrin of EU businesses. Combined with the absence of a significant agricultural sector in Singapore, ${ }^{87}$ this has greatly facilitated negotiations. The European service industry keenly supports the negotiations, especially the financial services sector. ${ }^{88}$ However, even with such enthusiasm from both sides, difficulties have arisen from the EU's extensive approach to FTAs including the incorporation of environmental and sustainability practices, which Singapore is reluctant to accept. ${ }^{89}$ As was the case in the KOREU negotiations, rules of origin are also a somewhat controversial issue, given the nature of international production chains, especially in East Asia. To qualify for preferential treatment under the FTA, the EU demands that substantial transformation occur in the FTA partner. The duty drawback clause in KOREU (Korea's non-negotiable condition) allowing Korean car manufacturers to claim back duties on imported components from their supply chain in South East Asian, was contested by EU member states, EU industries and the European Parliament. It was only accepted once a safeguard clause was incorporated into the agreement. One reason this proved so controversial was fear that it could serve a precedent for future agreements with other states (especially J apan). It is unclear whether this will also

\footnotetext{
84 F. Nicolas, op. cit, p. 42.

85 'Statement of President Barroso following his Meeting with Singaporean Prime Minister,' 5 Sept 2011, MEMO $11 / 580$.

$<$ http:// europa.eu/rapid/pressReleasesAction.do?reference=MEMO/11/580\&format=HTML\&aged=0\&language $=$ EN\&quiLanquage $=$ en $>$, accessed 10 December 2011.

86 S. Tay, Asia Alone: The Dangerous Post-Crisis Divide from America, Singapore, J ohn Wiley and Sons, 2010.

${ }^{87}$ Negotiations where a partner demands extensive agricultural liberalization from the EU have proven problematic. The main example lies in the negotiations with Mercosur. See M. Garcia, The 2002 Association Agreement between the EU and Chile: A Case of Successful Negotiations, New York, Edwin Mellen, 2009, chapter 3.

88 European Services Forum, 'Letter to Commissioner Karel De Gucht European Service Industry Priorities for EU-Singapore Negotiations' ESF 10/ 18, 19 J uly $2010<$ http:/ / www.esf.be/ new/ wpcontent/ uploads/2010/07/ESF2010-18-ESF-Priorities-for-EU-Singapore-FTA-Final.pdf>, accessed 20 J anuary 2012.

Faced with saturated markets in Europe and increased regulations, the financial services are hoping for liberalization elsewhere, and Singapore is already one of the key global financial centres.

89 'Big Prospects for Upcoming EU-Singapore FTA' 5 Nov 2010

<http:// www.europesworld.org/ NewEnglish/Home_old/CommunityPosts/tabid/ 809/ PostID/1975/language/ en -US/ Default.aspx>, accessed 20 J anuary 2012.
} 
apply to Singapore. At the time of writing it appears likely that the EU and Singapore will resolve outstanding differences and conclude an agreement. 90

In contrast, news releases and briefings from meetings with stakeholders reveal that ongoing negotiations with Vietnam, Malaysia and India are proving much more challenging. In September 2011, negotiations with Vietnam were merely entering the stage where specific areas to be included are discussed. The EU Head of Delegation in Malaysia claimed progress had been made but conceded in September 2011 that negotiations would be complicated. ${ }^{91}$ Problems arise from the EU's deep trade agenda, and its partners' more limited approach to FTAs. In particular, the EU's commitment to opening public procurement and services markets , conflicts with the developmental state policies that have been instigated by the leadership of these states, and is unlikely to be resolved quickly.

In a similar vein, negotiations with India which began two years before the individual ones with Vietnam and Malaysia, and were initially supposed to conclude in 2009, are ongoing. Public procurement, EU intellectual property provisions (and their effects on Indian generic medicine production), different preferences in the liberalization of services (with the EU wanting banking liberalisation, and India liberalisation in visas for short-term service provision in IT) have been significant stumbling blocs to speedier negotiations. ${ }^{92}$ Momentum was building in 2011 to finalise these in the first half of 2012 before potential elections in India and a change of government away from the more pro-European Congress Party, but this has not succeeded and final outcomes remain uncertain. Whilst the EU aims to achieve the same degree of liberalization it negotiated with South Korea, if it wishes to complete FTAs with other states in the region, to prevent disadvantages from these states' FTAs with EU competitors, it may have to increase the flexibility of its approach in terms of its counteroffers to interlocutors.

\section{Concluding remarks}

As the European Union has developed, its international aspirations and relationships have also evolved. Traditionally, its closer ties were with its key allies, neighbouring states and former colonies in the ACP group. In terms of economic relations, the states of Asia benefited from the GSP scheme but none of the EU's preferential trade agreements reserved for ACP states. Recent transformations in Asian economies (growth, market reforms, WTO membership) have increased economic interaction between European and Asia. Thus, Europe-Asia trade "now constitutes a 'third-link' in the global economy as trade volumes exceed traditional trade flows of each respective region with the USA." 93 To further facilitate EU business opportunities in Asia, the EU's trade policy since 'Global Europe' has focused on negotiating better access to key Asian markets through FTAs, turning these into a key priority area.

\footnotetext{
${ }^{90}$ Further analysis of its content will have to wait until such a moment when materials become available and when actors, having completed negotiations, are willing to discuss the matter with researchers.

${ }^{91}$ Malaysia Digest 'Fifth Round of EU-Malaysia Negotiations,' 30 September 2011,

$<$ http:// malaysiandigest.com/ business/32357-fifth-round-fta-negotiations-between-malaysia-eu-in-midoct.html>, accessed 20 J anuary 2012.

92 S. Khorana and N. Perdikis, 'EU-India FTA: Deal or No Deal,' South Asia Economic J ournal, Vol.11, No.2, 2010, pp. 182-206.

93 B. Gavin and A.Sindzingre, 'EU trade relations with Emerging Asia: identifying the issues,' Asia Europe J ournal, Vol.7, No. 9, 2009, p. 19.
} 
Welfare benefits are expected for the EU from FTAs, but these are meagre, with the real benefits stemming from influencing the future regulatory environment. A key impetus for this increased interest in FTAs in Asia has come from the EU's concerns of potential losses from agreements negotiated amongst competitors, especially as reaching global preferences at the WTO became more elusive. The timing of negotiations is telling in this regard, as EU negotiations lag behind USA ones, although in terms of application of agreements in some cases the EU has been able to overtake the USA (KOREU) and reap the first-mover advantage. Such observations lend credence to explanations of FTA expansion based on trade competition, ${ }^{94}$ and those based on policy emulation and competition. ${ }^{95}$ However, as the analysis of KOREU and KORUS has shown key actors also follow their own material motivations when pursuing FTAs. It is thus important for explanations to take into account sequencing factors and changing domestic preferences in order to fully understand the FTA phenomenon.

Although KOREU and KORUS are similar in content and very comprehensive, it remains to be seen whether other agreements will follow this trend. Whilst the EU wishes others to sign similar FTAs, partners are resisting EU proposals, motivated by their own economic policies and preferences. As global economic governance is redefined by overlapping FTAs (and not just EU and USA FTAs, but also Chinese, and those amongst other parties), it is uncertain whether they will give rise to compatible systems (KORUS and KOREU are broadly compatible) or contradictory elements, or whether one model will prevail over others. The EU's extensive and highly institutionalized approach covering other aspects beyond trade could afford it an advantage in terms of internationalizing its FTAs. The non-binding character and the EU's approach based on international rules (rather than mutual recognition) is also a reflection of its own internal diversity of preferences and its nature as a "conflicted trade power." 96 However, the USA's FTAs are more similar and more legally binding, giving it a clear immediate advantage in those concrete issues it negotiates. Thus far, Mike Mochizuki finds that the result of seeking influence through FTAs has meant that the large players have not used FTAs among themselves to counter competitive pressures, but have instead signed them with smaller states to hedge against negative trends, and this large power competition has prevented the predominance of any hegemonic FTA project. ${ }^{97}$ At the moment the 'FTA process.. more closely resembles fingers reaching idiosyncratically around the globe than the formation of politicoeconomic blocs centred respectively on Beijing, Brussels and Washington."98 To the extent that FTAs are negotiated (especially by the EU and USA) in a competitive fashion to counter fears of potential losses, it seems likely that current trends will continue.

In terms of our understanding of the FTA phenomenon, much of the analytical focus (as in this article) has been on the larger players in the global economy. They may be

\footnotetext{
94 R. Baldwin, 'A Domino Theory of Regionalism,' op. cit.

95 M. Solis, and S. Katada,'Explaning FTA Proliferation: A Policy Diffusion Framework', in M. Solis, B. Stallings and S. Katada (eds.), Competitive Regionalism: FTA Diffusion in the Pacific Rim, Basingstoke, PalgraveMacmillan, 2009.

96 S. Meunier and K. Nicolaidis, 'The EU as a Conflicted Trade Power,' J ournal of European Public Policy, Vol. 13, No. 6, 2006, pp.906-925.

${ }^{97}$ M. Mochizuki, 'Political-Security Competition and the FTA Movement: Motivations and Consequences', in M. Solis, B. Stallings and S. Katada (eds.), Competitive Regionalism: FTA Diffusion in the Pacific Rim, Basingstoke, PalgraveMacmillan, 2009, pp. 54-73.

98 G. Hufbauer and Y. Wong, 'Prospects for Regional Free Trade in Asia,' Peterson-Institute Working Paper Series No. 05-12, 2005, p. 12.
} 
the ones better positioned to extend their regulatory preferences through FTAs, however, as the preliminary findings reveal, medium-sized economies are taking a bolder stance at 'calling the shots' in negotiations, As their levels of economic interdependence with the largest economies is altered through diversification (not least through FTAs amongst smaller states) and the effects of the financial and economic crisis, the relative negotiating power of the EU and USA will decrease. 99 This could allow the smaller economies a greater role in shaping the future economic governance scenario. Future analyses more explicitly focusing on the structural power of negotiating partners in this context, would offer more leverage in understanding this phenomenon and its future implications.

\footnotetext{
${ }^{99}$ For how this has already begun, see S. McGuire \&J . Lindeque, 'Dimishing Returns to Trade Policy in the European Union,'J ournal of Common Market Studies, Vol. 45, No. 5, 2010, pp. 1329-1349.
} 